\title{
"What I Remember Clearly from our Conversations": Memory as the Method of Power Struggle in Michael Frayn's Copenhagen
}

\author{
“Konuşmalarımızdan Kesin Olarak Hatırladığım Şey:” Michael Frayn'ın \\ Copenhagen Adlı Oyununda Hafızanın Güç Savaşı İçin Kullanımı
}

\section{Emine Seda ÇAĞLAYAN MAZANOĞLU*}

\begin{abstract}
Werner Heisenberg, who worked for the Nazi German nuclear project, visited Niels Bohr in Copenhagen in 1941, who took part in Manhattan Project. However, the content of this meeting during World War II remained a mystery and has been a subject of speculation. The letters which Heisenberg and Bohr subsequently wrote revealed that both scientists narrated what they had discussed and why they had ended up bitter in different ways. In Heisenberg's memory he expressed his moral concerns about nuclear armaments; however, Bohr's memory led him to argue that Heisenberg had the intention of making an atomic bomb for Nazi Germany. Michael Frayn's Copenhagen (1998) is a fictional account of this meeting which had a profound impact not only on scientific memory but also on historical and political memory. Hence, the aim of this article is to argue that in Copenhagen the spirits of Bohr, Heisenberg and Margrethe engage in a power struggle and use their personal memories, which are all different, to get over the global trauma of the atomic bombs which destroyed Hiroshima and Nagasaki, and to evade responsibility. While the characters try to remember the real reason for Heisenberg's visit, they re-write the history of atomic bomb through their personal memories.
\end{abstract}

Keywords: Power Struggle, Personal Memory, Atomic Bomb, World War II, Quantum Physics

Öz: Alman nükleer projesinde yer alan Werner Heisenberg, Manhattan Projesi'nde çalş̧an Niels Bohr'u, 1941 yılında Kopenhag'ta ziyaret eder. Ancak İkinci Dünya Savaşı sırasında gerçekleşen bu görüşmenin içeriği bir sır olarak kalmıştır ve üzerine pek çok tahmin yürütülmüştür. Heisenberg ve Bohr'un daha sonra yazdığı mektuplar, iki bilim insanının da görüşmede tartıştıkları konuyu ve görüşmeyi aniden bitirme sebeplerini farklı şekillerde anlattıklarını ortaya koymaktadır. Heisenberg, nükleer silahlanmanın ahlaki boyutu konusundaki endişelerini dile getirdiğini hatırlar, ancak Bohr'a göre, Heisenberg, Almanya için atom bombası yapma niyetinde olduğunu belirtmiştir. Michael Frayn'ın Copenhagen (1998) adlı oyunu, yalnızca bilimsel hafıza üzerinde değil, aynı zamanda tarihi ve politik hafıza üzerinde büyük izler bırakan bu görüşmenin kurgusal bir anlatımını sunmaktadır. Bu sepeble, bu makale, Copenhagen oyununda Bohr'un, Heisenberg'ün ve Margrethe'ın ruhlarının bir güç savaşı içine girdiklerini ve Hiroshima ve Nagasaki'yi yerle bir eden atom bombasının yarattı̆̆ sorumluluğunu üzerlerinden atabilmek için, birbirinden farklı olan kişisel hafızalarını kullandıklarını tartışmaktadır. Oyundaki karakterler, bir yandan Heisenberg'ün ziyaret sebebini hatırlamaya çalışırken, bir yandan da kişisel hafızaları yoluyla atom bombasının hikâyesini yeniden yazarlar.

Anahtar sözcükler: Güç Savaşı, Kişisel Hafıza, Atom Bombası, İkinci Dünya Savaşı, Kuantum Fiziği

\footnotetext{
* Dr., Hacettepe University, Faculty of Letters, Department of English Language and Literature, Ankara. emineseda.caglayan@hacettepe.edu.tr.

"What I Remember Clearly from Our Conversations" ifadesi alıntıdır bk. "Doc. 1", 2.
} 


\section{Introduction}

On the $6^{\text {th }}$ of August, 1945 Hiroshima was hit by an atomic bomb which was dropped by Enola Gay (Selden 1989, xvii), and on the $9^{\text {th }}$ of August, 1945 Nagasaki was destroyed by the second atomic bomb which killed more than 60,000 people (Hogan 1996, 1). The bombings were followed by censorship imposed by the U.S. on "all discussion of the bombs" (Dower 1996, 116), which "reflected both the general U.S. policy of secrecy concerning nuclear matters and [...] the broad agenda of media control pursued as part of U.S. occupation policy in defeated Japan" (Dower 1996, 116).

The trauma caused by the bombings and the mystery surrounding both the event itself and the developments occured afterwards are dealt with in Michael Frayn's Copenhagen (1998) which presents the fictional account of a historical event that is Werner Heisenberg's visit to his tutor Niels Bohr in occupied Copenhagen in 1941 during World War II. The meeting between Bohr and Heisenberg is of significance, as will be dealt with in detail, because both physicists were involved in different projects developed to build atomic bomb, which ended their scientific collaboration and destroyed their close companionship. The content of the meeting of the two scientists working on nuclear physics at the beginning of World War II has remained complicated. David Barnett describes the content of Copenhagen as follows:

The play concerns three dead souls who try to fathom the mysteries of a meeting that took place between two of them in Copenhagen in September 1941. All three reference real people, the physicists Werner Heisenberg and Niels Bohr, and the latter's wife Margrethe, and a real event in which the long-standing friendship between Heisenberg and Bohr was rent asunder $(2005,139)$.

Therefore, in Copenhagen the spirits of Bohr, Heisenberg and Margrethe gather to shed light on the mystery of the 1941 meeting, and they try to remember what Bohr and Heisenberg exactly told each other about building atomic bomb and their parts in the projects.

The aim of this article is to argue the role of memory in shaping the social, political, scientific and ethical collective memories by means of personal memories of the spirits of Heisenberg, Bohr and Margrethe in Frayn's Copenhagen. In a sense, the collective memory, "something that was an intensely shared communal experience, the sum of a collection of separate but similar individual experiences" (Douglass \& Vogler 2003, 17), is reduced to the personal memories of the characters, each of which is different from and contradictory to each other. It will be argued that through their opposed memories, the characters confront one another. Particularly Bohr and Heisenberg are haunted by the sense of guilt, try to justify themselves, and evade responsibility for the development of atomic bomb. Thus, the nature of personal memories which is open to multiple interpretations and options will also be discussed. It will be displayed that for the characters, memory is "not a passive all-embracing record of our lives" but "it is an actively selective system which stores away some aspects of our experience but discard others" (Parkin 1999, 19). In other words, the characters are not in the forgetting process but bring back specific memories. Furthermore, the characters' return to the present as spirits is of significance because not only the characters but also their memories are ghosts and parts of the past. In a sense, the memories are in existence and, just like the characters, they haunt both the past and the present. It will also be demonstrated that the attempts of the characters, who have suffered the trauma of atomic bomb, to revive the memories of Copenhagen meeting connect the past where the actual meeting occured, and the present where the characters have the recollections of the meeting. Therefore, in Tereza 
Lesáková's words, "[m]emory has a fluid quality, which enables us to re-experience and rethink past events as if they were happening in the present" (2014, 23). As Margrethe says in the play, "[s]ome questions remain long after their owners have died. Lingering like ghosts. Looking for the answers they never found in life" (Frayn 1998, 3), Frayn's Copenhagen not only offers an insight to the lives of the two prominent physicists but also focuses on a significant question, which is the content of their 1941 meeting, that has not been answered yet. In this sense, first, the scientific work of Bohr and Heisenberg along with their scientific collaboration and close association will be presented. Then, in Copenhagen their use of personal memory in various drafts of the actual 1941 meeting to justify their roles in atomic energy projects during World War II, which turns into a power struggle between the characters, will be discussed. Moreover, the letters they wrote to each other and other people in real life and the notes will be examined in order to understand how each remembers the 1941 meeting, which is also reflected in Copenhagen.

\section{The Two Lives Devoted to Physics: Werner Heisenberg and Niels Bohr}

Heisenberg and Bohr, the two prominent physicists of the $20^{\text {th }}$ century, were colleagues and worked together in Copenhagen between 1924 and 1927 ("Werner Heisenberg - Biographical", 2014). Heisenberg (1901-1976), "physicist and philosopher, in helping to establish the modern science of quantum mechanics" (Magill 1999, 1619), "began his career in the 1920s and 1930s, during a time of great achievements in atomic physics" (Cropper 2001, 270). He began to work with Bohr in Copenhagen in 1924, and in 1926 after Hendrik Anthony Kramers accepted a professorship in Utretch, Heisenberg replaced Kramers as Bohr's assistant (Cassidy 1992, 185). During the time they worked together the two physicists were not only colleagues but they also formed a close friendship which developed throughout the years. David Cassidy puts forth the close bond between Heisenberg and the Bohrs as follows: "[Niels Bohr and Margrethe Bohr] [...] treated Werner as a family member, providing regular meals and access to their piano [...]" $(1992,219)$. Bohr and Heisenberg made excursions together like the walking tour in North Zealand and they talked about physics in seclusion (Heisenberg 1985, 96). Heisenberg states that his collaboration with Bohr widened his horizon as a scientist in the following words: "When we returned to Copenhagen after our walking tour, I felt that through Bohr I knew much more of the spirit of atomic theory of the future, than I had before" $(1985,97)$. During the time he was in Copenhagen, Heisenberg "deepened his knowledge of the atom and Quantum Theory" (Wilczek 2010, 13). Then in 1927 Heisenberg left Copenhagen for a professorship at the University of Leipzig, and "[he] returned to Copenhagen [...] almost every year for a few weeks to talk over with Bohr the problems which occupied [them] both [...]" (Heisenberg 1985, 108). The principle of uncertainty that Heisenberg proposed in 1927 was of great significance and had a vital place in the Copenhagen Interpretation as his work on quantum mechanics enormously contributed to the development of research on atom (Cassidy 1992, 91-92). After World War II broke out in 1939, Heisenberg began to work in the Uranium Project which was also known as Uranium Club where the scientists reached two conclusions: "a nuclear chain reaction was possible in natural uranium if it was initiated by neutrons whose energy had been reduced to low levels in a 'moderator,' either heavy water or graphite. They were also convinced that the rare isotope uranium 235 could be used as a nuclear explosive" (Cropper 2001, 271). After Germany was occupied by the Allied Forces, the German scientists, including Heisenberg, were taken to Farm Hall in Cambridgeshire in fear that they would go to the Soviet Union. Their conversations were monitored by the Allied Forces, and they received the news of bombing of Japan while they were in captivity (James 2004, 351). They were kept at Farm Hall until 1946 
only after which they could return to Germany (Wilczek 2010, 23). Heisenberg also worked as the director of the Kaiser Wilhelm Institute for Physics in Berlin after 1941 and worked on a nuclear reactor. After the war ended, Heisenberg was appointed as the director of the Max Planck Institute for Physics and Astrophysics in Göttingen, in 1958 left Göttingen as the Institute moved to Munich (Magill 1999, 1618), and worked as the director of the Institute until he retired in 1970 (James 2004, 353). There have been different opinions regarding Heisenberg's commitment to the German cause during the war. These different views may be put forth as follows: Heisenberg supported Hitler, or he was working against Hitler, or his only and main concern was Germany. In this regard, Abraham Pais stated: "All I have heard and read leaves me without doubt that Heisenberg was neither a Nazi nor a Nazi sympathizer, yet that he had tied his fate to that of Germany" (1991, 484-485). For Reimar Lüst, Heisenberg "was not a nationalist but a patriot" and "(h)is love of Germany" was always on the foreground (2004, 16). In 1926 there were two job offers from the Universities of Zurich and Leipzig, which he preferred the latter (Lüst 2004, 16). In Lüst's words, "Germany was for him the country in which he had spent a fulfilled and exciting youth. It was where he felt he belonged" (2004, 16). Similarly, in 1939 Heisenberg delivered lectures in Ann Arbor and Chicago and he was offered to stay in America, yet he rejected the offer because "such a step would be a betrayal of those young Germans for whom he felt responsible" (Pais 1991, 482). In a letter which he wrote to Elisabeth Heisenberg on the $13^{\text {th }}$ of July 1939 he says:

This morning I again had a long talk with the head of the department, who would like to invite me here more often. Also, I have been asked by other a few times under what conditions I would permanently come here. The two aspects, light and shadow, are so immensely clear. I am treated fabulously in every way. I would have ten times as many bright students as where we are. It would probably also affect the results in my work positively. But we just are not at home here. The children would speak English and grow up in an atmosphere that is foreign to us (Heisenberg 2016, 65).

However, though Pais states that Heisenberg was apolitical, he also raises the following questions regarding Heisenberg's acts: "Why should he have chosen to come to Denmark in 1941 under the auspices of an organization that most Danes detested? Why should he have visited Bohr at all to talk about atomic weapons? [...] Why did he not realize that it would be preferable to keep his convictions of a German victory to himself rather than alienate others?" (1991, 485). Therefore, though the general opinion is that Heisenberg worked for Germany and the German regardless of politics, his visit to Copenhagen in time of war posed questions about his intentions.

The other remarkable physicist Niels Bohr (1885-1962) started to work as a professor in theoretical physics in Denmark in 1916 ("Niels Bohr-Biographical", 2014), and in 1917 he became a member of Royal Danish Academy of Sciences and Letters (Rosenfeld and Rüdinger 1985, 69). Between 1920 and 1962, he directed the Institute for Theoretical Physics in Copenhagen ("Niels Bohr - Biographical", 2014). In 1927, he introduced the concept of complementarity (Plotnitsky 2013, 4). After World War II started, a project on atomic energy started in England and after his escape from Denmark in 1943, Bohr became a part of the Allied atomic weapons program. Then a team, which included Bohr and his son Aage Bohr, was sent to America to work at Los Alamos laboratory in New Mexico (Bohr 1985, 196-197). In the undated notes which were noted down by Aage Bohr, Bohr describes the collaboration of 
America and England as "the great American-English preparations" ("Document 9", 1, "Document 1", "Document 5a", "Document 6", "Document 7", "Document 9", "Document $11 \mathrm{a}$ " were quoted and paraphrased throughout the essay by permission of the Niels Bohr Archive, www.nbarchive.dk), and points out that German efforts on the development of atomic weapons were the main concern of the scientists taking place in the project ("Document 9", 1). In other words, the English and American scientists started to work on building atomic bomb because they were concerned about the possibility that the German physicists had already launched the atomic bomb projects. Bohr also states that while he expressed his opinions about the work conducted by Germany to the English secret service and other authorities in the English government, he informed them about his own impression of the 1941 meeting with Heisenberg as follows: "[...] and I naturally reported all of our experiences including in particular the impression I got both during the visit to Copenhagen by [Heisenberg] and Weizsäcker [...]" ("Document 9", n.d., 1). The American and English atomic physicists were led by Robert Oppenheimer in Los Alamos (Bohr 1985, 200). As Aage Bohr explains, during the time Bohr worked in Los Alamos he was mainly concerned about the serious effects of atomic bomb which would be experienced not only during the war but also in the post-war period $(1985,197-198)$.

After Germany occupied Denmark, the German Cultural Institute was founded in Copenhagen. In October 1941, Heisenberg and C. F. von Weizsacker were sent to Copenhagen to give public lecture at astrophysics meeting. Although Bohr and other members of the Institute for Theoretical Physics were invited, none of them participated the lecture (Pais 1991, 483). In an undated draft of document in Margrethe Bohr's handwriting the organisation is described in the following words: "Through the German authorities Heisenberg and Weizsäcker had arranged a physics conference at the German Institute in Copenhagen, which had been established by the occupying power. Only a few Danes took [part] in this conference, and among them none of the leading physicists at the University's Institute for Theoretical Physics" ("Document 6", 1). Therefore, the visit from the German physicists during the war, regardless of the reason, received a negative response from the Danish scientists. After the lecture, Bohr and Heisenberg had a private meeting whose detail is not known because neither "made an immediate record of what was said" and "[t] heir later recollections are conflicting to some extent" (Pais 1991, 483). Therefore, in Matthias Dörries's words, "[...] it will be forever impossible to reconstitute Heisenberg's and Bohr's actual conversation" (2005, ii). And the meeting of the two pioneers of quantum physics who separately worked on nuclear energy during World War II before the use of atomic bombs in Hiroshima and Nagasaki has raised a question mark in the minds of the researchers for years. The Copenhagen meeting "remains of interest more than sixty years later because the uncertainties that continue to surround it reflect deeper questions of interest to us all" (Dasenbrock 2004, 218). In this sense, Peter Young asked: "Why did the German physicist, who was not a Nazi even though he worked on atomic energy research for his government, go to see Bohr, his half-Jewish friend and mentor then on the opposite side and working in occupied Denmark?" $(1999,218)$. Moreover, as in Frayn's words, "[...] it's a very unclear area. [...] a very uninvestigatable area" (as cited in Wu 2000, $223)$ and "[t]here must have been some purpose behind it, but no one has ever been able to give a satisfactory account of what it was" (as cited in Wu 2000, 216). Aage Bohr (1985) asserted that in their private talk Heisenberg mentioned the use of atomic energy for military purposes; however, Niels Bohr had serious doubts as to the applicability of such method. Niels Bohr's feeling after the 1941 meeting was that Heisenberg believed in the use of new methods to end the war (193). Therefore, although notably their colleagues and the British intelligence service 
struggled to learn about the hidden side of their conversation not only in course of the war but also after the war, it is not exactly and clearly known what the two physicists talked about in the meeting (Young 1999, 218). Furthermore, misunderstandings in such a conversation were certain because as Dörries stated, "[i]n the year 1941, the private and political spheres had become inseparable, making any confidential conversation between two representatives of enemy powers impossible from the start", and "[e]ach participant was in a situation in which he could not know what the other thought, nor whether the other could evaluate what he himself thought" (2005, vii). Thus, it may be argued that given the wartime conditions when the two parties would be spied on by the secret services and they were unable to express their views on the use of nuclear weapons, the misunderstandings during their conversation and the following contrary statements on the content of the meeting were inevitable.

In this respect, by displaying the incompatible attitudes of the physicists, Frayn's Copenhagen "has renewed and strengthened an already intense debate among historians of science about why Heisenberg came to Copenhagen and what transpired at the meeting" (Aaserud 2000, para. 1). In Act One, the meeting is re-enacted for three times as the characters try to find cause and effect relationships in their actions and statements, and start over once and again. In Act Two, they revive the meeting for once. Moreover, the collaboration of Bohr and Heisenberg between 1924-1927, "when (Heisenberg) arrived in Copenhagen to work with (Bohr)" and "when (he) departed, to take up (his) chair at Leipzig" (Frayn 1998, 61), is highlighted. Thus, it may be argued that "Copenhagen explores the multiple memories and versions of what may have actually happened (...)" (Young 1999, 219). According to Harry Lustig and Kirsten Shepherd-Barr, each re-enactment leads to distinct conclusions and "(n)o concrete answers are provided in the text. Even the characters' own memories of the events prove unreliable" $(2002,552)$. In each recollection of the visit the three characters remember new details about the very beginning of the meeting, that is their greeting each other and the events in which the three of them were involved, and the following private conversation between Heisenberg and Bohr. The questions as to the reason for Heisenberg's visit are repeatedly asked throughout the play as the characters over and over return to 1941, recapture the past and ask the same questions with the hope of finding the answers. None of the characters certainly remember what happened in their meeting and why that meeting occured. Margrethe opens the play asking, "Why did he come? What was he trying to tell you?" (Frayn 1998, 3). Bohr is doubtful whether Heisenberg himself knows why he came to Copenhagen in 1941 and says: "I doubt if he ever really knew himself" (4). Margrethe emphasises Heisenberg's futile efforts to explain his cause: "He explained over and over again. Each time he explained it became more obscure" (3). Also Heisenberg complains that no matter how hard he tried to express himself not only to Bohr and Margrethe but also to the "interrogators and intelligence officers, to journalists and historians" (4), he failed to remove uncertainty surrounding the meeting: "The more I've explained, the deeper the uncertainty has become" (4). In Act One, the characters maintain uncertainty through constant questioning. Bohr asks: "What do you want to know?" (19) while Heisenberg asks himself: "And what exactly did Bohr reply? [...]" (34). Margrethe acts as a mouthpiece of both physicists and asks: "What did Heisenberg tell Niels what did Niels reply?" (35).

\section{III. "Settled among all the Dust we Raised (Frayn 1998, 93)": Whom to Blame?}

Even from the beginning of the play the unrealibility of personal memory is presented. The characters remember and narrate the same event in different ways and insist on the authenticity of own memories. Though Bohr says that he shot George Camow, a colleague who claimed that 
"it was always quicker to act than to react" (Frayn 1998, 26) and bought pistols for both to use when it was time to prove his theory, Heisenberg insists that it was Hendrik Casimir. In this regard, Heisenberg says: "And poor Casimir has been blasted out of existence"; and Bohr replies in anger: "Except that it was Gamow" (27-28). Eventually, Bohr is defeated by the vagueness of his personal memories and in despair says: "Yes, well, one of the two" (28) as Heisenberg expresses that their memories play tricks on them in the following words: "Both of them simultaneously alive and dead in our memories" (28). Therefore, it may be deduced that the personal memories may be uncertain, and with the passing of time, varied images about the same event or personage may be created in the minds of the witnesses. In the play, this vagueness in the personal memories may also be associated to the multiple possibilities that are raised in decision making process. In other words, the numerous probabilities of decisionmaking may be compared to the contrasting images of personal memories. In both situations, there are various options which may make one be caught in a dilemma. Heisenberg explains the similarity between the vagueness of personal memories and the uncertainty of decision making through skiing metaphor. In this respect, he says: “(...) Decisions make themselves when you're coming downhill at seventy kilometres an hour. Suddenly there's the edge of nottingness in front of you. Swerve left? Swerve right? Or think about it and die? In your head you swerve both ways ..." (25). Thus, the personal memories and decision making may lead one to a state of deadlock, which is no different from the sense of ambiguity that prevails in life: "Margrethe: $O r$ Schrödinger's wretched cat. / Heisenberg: That's alive and dead at the same time" (25), and "Heisenberg: So the particle's here, the particle's there ... / Bohr: The cat's alive, the cat's dead ... / Margrethe: You've swerved left, you've swerved right ..." (26).

The two physicists first confront each other in the first re-enactment in Act One. Heisenberg openly tells the reason for his visit claiming that he was very clear in his intentions and it had never been a mystery. He remembered well because his life was in jeopardy and he paid utmost attention to his statements. He asked Bohr "if as a physicist one had the moral right to work on the practical exploitation of atomic energy. [...]" (Frayn 1998, 36). However, Bohr expresses that he does not remember this particular moment, and Heisenberg accuses Bohr of having overreacted and "[standing] there gazing at [him], horrified" (36). Heisenberg asserts that Bohr uses "not remembering" as means of escapism and he was so biased towards him that he even did not listen to his explanations, which is described by Duncan Wu as "Bohr's angry, indignant rejection of Heisenberg" $(2000,212)$. Though Bohr previously says that he does not recall what Heisenberg told him, he now says that "the implication was obvious" (Frayn 1998, 36) and Heisenberg was "working on it" (36). In response to Bohr's reaction, Heisenberg, feeling disappointed, realises that Bohr "[...] jumped to the conclusion that [he] was trying to provide Hitler with nuclear weapons" (36). At this point, Heisenberg admits that he was working on a reactor, "[a] machine to produce power! To generate electricity, to drive ships!" (36). However, he also adds that he was worried because "[i]f [they] could build a reactor [they] could build bombs" (37). When Bohr accuses Heisenberg of not having talked about the reactor, Heisenberg professes that at the time of their meeting it was impossible to explain issues in detail and openly because they were rigorously monitored, and despite their personal and scientific affiliation, they represented the two enemy states: "I didn't say anything about anything! Not in so many words. I couldn't! I'd no idea how much could be overheard. How much you'd repeat to others!" (36). In this regard, Heisenberg reveals that he had a distrust of not only the secret services but also Bohr himself. He also admits that he had to riddle and expected Bohr to understand his intentions rather than overreact and end the conversation so soon. Heisenberg expresses his confusion over Bohr's reaction in the following words: "[...] And at this point you stopped listening. The bomb had already gone off inside your head" (37). Margrethe's brief comment on their mood after the conversation gives clue about how their talk 
ended: "[...] Only from the look on their faces something even worse has happened" (32). Hence, at the beginning of the play Frayn presents the historical fact that the two parties were anxious during their conversation due to the fear of being monitored; they did not feel free to talk about issues related to war openly and they probably misinterpreted their statements.

Similar to the statements of the two physicists fictionalised in Copenhagen, in their letters, which they wrote in real life after World War II, the physicists gave contradictory accounts of their talk. As Young said, "[Bohr] later gave one version of their meeting, Heisenberg another, further clouding matters" $(1999,218)$. In his letter dated $18^{\text {th }}$ of January 1957 to Robert Jungk, the author of Brighter Than a Thousand Suns (1956), Heisenberg asserts that during wartime in Germany a group of physicists worked on building a reactor which would produce energy and uranium that would be used as an explosive in atomic bombs. However, though he stresses the technical difficulty of making an atomic bomb with the possible resources, he also states that it was not impossible if "every conceivable effort" (Heisenberg 1957, n.p.) was used, which urged him to visit Bohr because "[t]he prospect of producing atomic bombs while at war was at the time immeasurably greater on the American side than on the German, due to the whole prior history. Since 1933 Germany had lost a number of excellent German physicists through emigration [...]. In the United States, however, many university institutes since 1932 had been given completely new and modern equipment, and been switched over to nuclear physics" (Heisenberg 1957, n.p.). In the following excerpt taken from Heisenberg's letter to Jungk, Heisenberg reveals that he was aware of the fact that both Bohr and himself were being monitored by the German forces, and hence he was highly cautious while he was unintentionally bringing up the possibility of using atomic energy during the war. In this regard, he explains the content of their conversation as follows:

The conversation probably started by me asking somewhat casually whether it were justifiable that physicists were devoting themselves to the Uranium problem right now during times of war, when one had to at least consider the possibility that progress in this field might lead to very grave consequences for war technology. Bohr immediately grasped the meaning of this question as I gathered from his somewhat startled reaction. He answered, as far as I can remember, with a counterquestion "Do you really believe one can utilize Uranium fission for the construction of weapons?" I may have replied "I know that this is possible in principle, but a terrific technical effort might be necessary, which one can hope, will not be realized anymore in this war." Bohr was apparently so shocked by this answer that he assumed I was trying to tell him Germany had made great progress towards manufacturing atomic weapons. In my subsequent attempt to correct this false impression I must not have wholly succeeded in winning Bohr's trust, especially because I only dared to speak in very cautious allusions (which definitely was a mistake on my part) out of fear that later on a particular choice of words could be held against me (1957, n.p.).

However, it is extremely confusing for the reader that Heisenberg cannot fully remember what the physicists exactly said to each other. At the very beginning of his letter, he says: "In my memory which may, of course, deceive me after such a long time, the conversation roughly unfolded the following way" (Heisenberg_1957, n.p.). He even cannot recall the exact date of the visit and says: "My visit to Copenhagen took place in the fall of 1941; I seem to remember that it was about the end of October" (Heisenberg_1957, n.p.). And while he is concluding the letter, 
he asserts that the reason why he cannot clearly and correctly remember their talk is their highly "complicated psychological situation" in course of their meeting. He remembers, though, how upset he was after their conversation, and states that he still suffers while writing the letter "since the wording of the various statements can certainly not be accurate anymore [...]" (Heisenberg 1957, n.p.). In Atomic Bomb Scientists: Memoirs Heisenberg also explains that during the war the German scientists were provided by the government the necessary resources to work on atomic energy. Though the German government planned to "make use of physics for warfare", the physicists thought that they "must make use of warfare for physics. [...]" (as cited in Ermenc 1989,23). They were also aware of the fact that making atomic bomb was demanding and would last long though it was not impossible (as cited in Ermenc 1989, 23). Therefore, they "could plan to use this [atomic] reaction for power plants for submarine and other applications" (as cited in Ermenc 1989, 32). Furthermore, Heisenberg clearly states that the German scientists intentionally did not inform the German authorities about the possibility of making atomic bomb so that they would not be obliged to produce it. And they did not believe that the Americans could produce it before the war ended (as cited in Ermenc 1989, 26-27).

The uncertainty over the 1941 meeting increased after Bohr's reply to Heisenberg's statements, which were published in Brighter Than a Thousand Suns, was found. As Finn Aaserud (2000) wrote, "[t] he draft letter was found some years after Bohr's death in his personal copy of the Danish edition of the book from 1957 [...]" (para. 5). For Bohr, Heisenberg's account in this book "has created such keen public interest in all these wartime connections" ("Document 9", n.d., 2). In this draft of letter which was not sent to Heisenberg, Bohr fiercely refutes Heisenberg's version of their meeting and says: "I think that I owe it to you to tell you that I am greatly amazed to see how much your memory has deceived you in your letter to the author of the book, excerpts of which are printed in the Danish edition" ("Document 1", n.d., 1). He, furthermore, asserts that he remembers well every detail of their conversation, and Heisenberg implied that the Germans were working on building atomic bomb ("Document 1", n.d., 1). Bohr also justifies himself stating that he learned about the developments in research on nuclear power conducted in England and America only after he escaped to England so that he would not be arrested by the German forces ("Document 1", n.d., 2). Similarly, in his incomplete and unsent draft of letter to Heisenberg, Bohr states that he remembers their meeting absolutely differently than Heisenberg describes in Jungk's book. According to Bohr, Heisenberg told him that the atomic weapons would determine the winner of the war if the war did not end imminently. And Bohr is under the impression that the German scientists led by Heisenberg worked on the use of atomic energy for military purposes ("Document 7", n.d., 2). In addition, in an incomplete draft of a letter which was not sent to Heisenberg, Bohr puts forth his impression of the meeting and what he remembers. He asserts that Heisenberg's aim was to check Bohr and Margrethe; however, he did not consider that he also jeopardised their safety ("Document 11a" n.d., 2). Bohr once again writes about his version of the meeting based on his memory and accepts that he paniced during their brief conversation because Heisenberg implied that it was possible to produce atomic weapons, and Heisenberg, in fact, did not say that the German scientists were working to prevent such production ("Document 11a" n.d., 3). In both "Document 7" and "Document 11a" Bohr refers to the fact that Heisenberg's ideas might have changed in the course of the war. In "Document 7" Bohr accuses Heisenberg of not remembering what he thought and said at the beginning of the war (n.d., 3). Similarly, in "Document 11a" Bohr attacks Heisenberg for changing sides: "Naturally, we understand that it may be difficult for you to keep track of how you thought and expressed yourselves at the various stages of the war, the course of which changed as time passed so that 
the conviction of German victory gradually had to weaken and finally end with the certainty of defeat" (n.d., 2). Hence, it may be argued that according to Bohr, Heisenberg's attitude to the German cause changed as the possibility of Germany's victory decreased. In other words, Heisenberg adopted different positions throughout the war, which may be regarded as one of the reasons for the uncertainty surrounding their private meeting ("Document 11a", n.d.). In this sense, in Klaus Gottstein's words, "[t]he documents recently released by the Niels Bohr Archive do not, in an unambiguous way, solve the enigma of what happened during the critical brief discussion between Bohr and Heisenberg in 1941 which so upset Bohr and made Heisenberg so desperate. But they are interesting, they show what Bohr remembered 15 years later" $(2002,1)$.

Like Heisenberg, also Bohr has difficulty in remembering the past events regarding the time of war in real life. In his draft of letter which is dated $27^{\text {th }}$ of December 1961 and was not sent to Heisenberg, Bohr refers to the questions asked to him about "the role of nuclear physics in the dark times", and he states that in his mind he does not have a clear picture of events. Furthermore, he expresses his hope to be able to meet Heisenberg in order to talk about the 1941 meeting, which he writes as "in 1942(?)", and to correct the misunderstandings ("Document 5a", 1). Therefore, it may be argued that through their contradictory memories the only witnesses of the 1941 meeting avert the possibility of knowing the actual content of the conversation. Alan Baddeley, referring to Sir Frederick Bartlett's study, says that

(...) in the process of remembering a passage the first thing the subject tends to recall is his or her attitude towards it (...). In short, what you remember is driven to some extent by your emotional commitment and response to the event. (...) Try, for example, asking two participants in a quarrel for an objective account of the dispute, or even ask the supporters of two opposing football teams for a summary of a particular game. Under such conditions two different versions are likely to emerge $(1999,97)$.

Hence, each physicist remembers and tells the event from his own point of view, and stick to their own personal memories while trying to invalidate each other's argument. In a sense, the actual letters and notes resemble the various drafts of the meeting in Copenhagen because in each letter and note, the meeting is re-enacted by the physicists to remember what they talked about.

In Copenhagen in the second re-enactment in Act One, the two physicists rewrite the scientific and political history and shed light on the underlying cause of a global trauma. Heisenberg explains how he was torn between his responsibility to humanity as a scientist and his love for his country during his visit to Copenhagen. He was uneasy about Bohr's position in the nuclear weapons production and was afraid that if he was asked by the German forces to produce a nuclear bomb, he had no alternative. That is why, he visited Bohr to "know if there [was] [the Allied nuclear programme]" (Frayn 1998, 41-42). Through the re-enactment the past and the present merge and the characters get into the 1941 meeting in the present time. For Heisenberg, both the German state and the Allied Forces will ask the scientists to produce atomic bomb. He says: "We are the ones who will have to advise them whether to go ahead or not. In the end the decision will be in our hands, whether we like it nor not" (40-41). When Bohr asks, "That's why you have come all this way, with so much difficulty? That's why you have thrown away nearly twenty years of friendship? Simply to tell me that?" (41), Heisenberg's reply, "Simply to tell you that" (41), turns a new page in the discussion on the reason for Heisenberg's visit in 1941. For the first time in the play Heisenberg refers to the fact that the 
scientists working in the field of nuclear energy had a heavy responsibility to mankind because they were the ones who had knowledge of developing the weapon of mass destruction. He also explains his current duty in the German nuclear programme and expresses his fears that if he is suspended from his duty, Kurt Diebner, who supports Hitler will replace him, and the development of atomic bomb will become unavoidable. Thus, Heisenberg struggles to maintain control and needs to get information from Bohr about the Allied Project (40). He also expresses that he wants to learn whether the Allied Forces are working on a nuclear bomb to use against Germany for two reasons: First, he points to his devotion to Germany saying, "Germany is where I was born. Germany is where I became what I am" (42). Secondly, this time he wants to take sides with the powerful as he remembers his childhood memories which are full of fear, death and escape under the terror of civil war. And the fact that it is in his power to prevent the German from suffering the horrors of war drives him to desperation: "Another nightmare like the nightmare I grew up with? [...] Are more children going to starve, as we did?" (42). Heisenberg, in a way, presents his love for his country and countrymen, which justifies his questionable role in the development of nuclear weapons to the audience/readers. However, it may also be argued that Heisenberg's statements are confusing because on the one hand, he asserts that there is not an ongoing project on nuclear weapons in Germany and all the physicists should act for the benefit of mankind if they are asked to work on atomic bomb; on the other hand, he implies that if there is any possibility that the Allied Forces defeat Germany by using atomic bomb, then he is ready to take any necessary action in order to protect the German from the atrocities of war. Based on Heisenberg's account of the reactions of the German physicists when they heard about the attack against Hiroshima, it is also possible to argue that Heisenberg and the German scientists were caught in a dilemma. His statement, "I can't describe the effect it has on us. You play happily with your toy cap-pistols. Then someone else picks it up and pulls the trigger ... and all at once there's blood everywhere and people screaming, because it wasn't a toy at all [...]" (46), gives the audience/readers the impression that the German scientists were extremely shocked at the use of atomic bomb. However, the statement also vividly displays that the German scientists were fully aware of the fact that they could make atomic bomb though they only worked on a reactor. Therefore, they regarded the possibility of developing atomic bomb as their own toy gun with which they could play but when it was built by the Allied Forces, it was no longer a toy gun because it was turned into a real gun, which killed so many people, by the other party. And when Margrethe asks a tricky question to understand the reason for their confusion, "Because it had been done? Or because it wasn't you who'd done it?" (46), Heisenberg's reply, "Both. Both" (46), clearly demonstrates that the ethical values and scientific ambitions of the scientists were and are still in great conflict.

Opposing Heisenberg's defence, Bohr puts forth that the scientists working for the Allied Forces also felt concern for the safety of their countries. Bohr says that the reason "why Allied scientists worked on the bomb" was simply the increasing menace of the German forces, "[t]he same fear that was consuming [Heisenberg]. Because they were afraid that [the German forces] were working on it" (Frayn 1998, 44). Hence, for Bohr, the scientists of the Allied Forces were as right as the German physicists in working on atomic bomb. However, Heisenberg blames all the scientists who played a part in making atomic bomb for the disastrous consequences, and once again reminds the audience/readers of the fact that the scientists are accountable to humanity for their acts. He states that the scientists could still overcome their fear and think rationally: "Did a single one of them stop to think, even for one brief moment, about what they were doing? Did Oppenheimer? Did Fermi, or Teller, or Szilard? Did Einstein, when he wrote to Roosevelt in 1939 and urged him to finance research on the bomb? Did you, when you 
escaped from Copenhagen two years later, and went to Los Alamos?" (43). According to Heisenberg, the Allied Forces did not have "the slightest conception of what happens when bombs are dropped on cities" (43), and though they "weren't supplying the bomb to Hitler" (43) as Bohr says to accuse Heisenberg, they were still "dropping it on anyone who was in reach. On old men and women in the street, on mothers and their children" (43), which was unjustifiable. Hence, the following question is posed: Could the physicists avoid the making of nuclear bomb and save all the living creatures who/which died? Heisenberg and Bohr question such possibility by asking questions to each other trying to remember what they argued about in the Copenhagen meeting: "Heisenberg: But, Bohr, you could have told them!" / Bohr: Told them what? I Heisenberg: What I told you in 1941! That the choice is in our hands! In mine - in Oppenheimer's! That if I can tell them the simple truth when they ask me, the simple discouraging truth, so can he!" (44). And "the simple discouraging truth" was that "nuclear weapons will require an enormous technical effort" and "will suck up huge resources" (40). And Bohr suddenly concludes that he now clearly understands the reason for Heisenberg's visit which is motivating Bohr to prevent the Allied Forces from building atomic bomb. Therefore, Heisenberg did not meet Bohr to learn about the progress the Allied Forces had achieved in nuclear research but as in Heisenberg's words, "[to] stop it together" (44). Heisenberg, referring to the responsibilities of scientists, implies that the physicists working for the Allied Forces and Germany could all together hinder the production of such a deadly weapon and says: "It's a hope. Not even a hope. A microscopically fine thread of possibility. A wild improbability. Worth trying, though, Bohr! Worth trying, surely!" (44).

Bohr's stance towards the use of nuclear energy to build atomic bomb is questioned through his work in Los Alamos. His function in Los Alamos raises a question mark in not only Heisenberg's and Margrethe's minds but also in the minds of the audience/readers. Margrethe supports that the decision to work on atomic bomb in Los Alamos had already been given before Bohr went there (Frayn 1998, 46). However, Heisenberg gradually puts forth Bohr's role in the making process through his indirect questions. Though he asserts that Bohr was a good man and did not do anything wrong (46-47), he displays Bohr's guidance in the project. The following conversation between the two physicists reveals that Bohr was also a part of the project regardless of the significance of his position: "Heisenberg: [...] Oppenheimer said you made a geat contribution. / Bohr: Spiritually, possibly. Not practical. / Heisenberg: Fermi says it was you who worked out how to trigger the Nagasaki bomb. / Bohr: I put forward an idea" (47). Thus, though Bohr says that he just gave the scientists some suggestions but did not actually work to make the bomb, Heisenberg insists that Bohr was the key person. Margrethe's support for Bohr claiming that Heisenberg tries to evade responsibility and to make Bohr feel "conscience-stricken" (47), which may be considered as an attempt to shift Bohr's responsibility, is, however, not accepted by Bohr himself because he was aware that he was somehow involved in the research on nuclear energy. When Margrethe says, "Niels, you did nothing wrong!" (91), Bohr's reply, "Didn't I?" (91), vividly shows that he questions his own part during the war. In regard to Heisenberg, he complains about his post-war experiences saying, "So explaining and defending myself was how I spent the last thirty years of my life. When I went to America in 1949 a lot of physicists wouldn't even shake my hand. Hands that had actually built the bomb wouldn't touch mine" (47). Therefore, he blames the scientists working in America for the trauma of the atomic bomb and regards himself innocent before them. However, it may be argued that his following words to Bohr, "(...) You were a good man, from first to last, and no one could ever say otherwise. Whereas I ..." (91), also raise doubts as to his perception of his own role. 
In the second re-enactment in Act One, Bohr also puts forth the idea that even if he acted differently during their conversation, and contrary to their first re-enactment, he did not end the talk suddenly, nothing would change. According to Heisenberg, Bohr gave him absolution as he "muttered something about everyone in wartime being obliged to do his best for his own country" (Frayn 1998, 39). However, Bohr reveals that he does not remember his statement saying, "Heaven knows what I said" (39), and expresses that he now understands what Heisenberg actually needed in the 1941 meeting: "You don't want absolution. I understand. You want me to tell you not to do it" (39). In this sense, he wants Heisenberg to return to Germany and tell his colleagues that Bohr advises them not to provide Hitler with "an improved instrument of mass murder" (39). Then his question, "What happens? You all fling down your Geiger counters?" (40), demonstrates that Bohr does not believe in a possible change in the course of events even if he told Heisenberg what he really wanted to hear, and hence, he rejects the accusations made by Heisenberg. From this point of view, it may be argued that the question, "what would happen if one acted differently?" is asked throughout the play through personal memories on both scientific and private matters though convincing answers are not provided. When the characters remember the death of Bohr's and Margrethe's son, Christian, and begin to question whether it was possible to prevent the accident on the boat, they conclude that some incidents are only remembered but never talked about "[b]ecause there's nothing to be said" (30). In a sense, it is idle to speculate about the possibility of changing the course of particular events like the death of the beloved or the making of atomic bomb.

In Act Two, the characters' facing their past acts through personal memories and confronting each other becomes serious, which leads them to make progress in order to uncover the mystery of Heisenberg's visit. On Margrethe's dreadful accounts of the consequences of atomic bomb, Heisenberg gives contradictory statements as, on the one hand, he abdicates responsibility saying, "I can only say that I didn't do it. I didn't build the bomb" (Frayn 1998, 79). On the other hand, when Margrethe explains that the only reason is that "[he] couldn't. [He] couldn't understand the physics" (79), Heisenberg, angry with being defamed, says: "I understood very clearly. I simply didn't tell the others" (80). Then, as the conversation progresses, it is revealed that Heisenberg told the working of atomic bomb only to Otto Hahn at Farm Hall after the first explosion; however, Heisenberg's calculations of "the figure for Hiroshima bomb" (81) were wrong. Heisenberg did not do the calculation because in his words, "[...] Frisch and Peierls did do it. It was a stupid waste of time" (85). The extent of the massive destruction was also discussed if Heisenberg had made the calculation for Germany, that is, the destruction of London, Paris, Amsterdam and maybe Copenhagen (84). In the final draft of the visit the question which is asked in the second draft of the visit in Act One is raised. Heisenberg asks: "Does one as a physicist have the moral right to work on the practical exploitation of atomic energy?" (88). Bohr looks at Heisenberg's face in shock, turns his back and the two return to the house, and as Heisenberg says, "Our conversation's over" (88). Just after Margrethe puts an end to the revivals of the visit saying, "And everything about him becomes as uncertain as it was before" (88), Bohr wants them to re-enact and see what would happen if he remembered his paternal role and asked Heisenberg "why" instead of leaving in anger (89). Therefore, the last 'what if' concerning the Copenhagen meeting of 1941 is enacted. Though the time will eventually come "[w]hen no more decisions, great or small, are ever made again. When there's no more uncertainty, because there's no more knowledge" (94), the particular moment that the ghosts of the three characters live in Copengahen is real, and despite the dimness of their personal memories, in Heisenberg's words, "[...] some event that will never quite be located or defined" has not been unfolded but has been immortalised (94). 
At this point, it is also essential to demonstrate how Frayn presents the fact that physics and politics are inseparable especially in wartime although the two scientists tried to stay out of politics in their real lives and maintained in their statements that their only concern was science. In the play Margrethe wants Bohr not to digress from physics in his conversation to Heisenberg and asks: "You won't talk about politics?" (Frayn 1998, 10). Although Bohr promises to follow her advice saying, "[w]e'll stick to physics. I assume it's physics [Heisenberg] wants to talk to me about" (10), throughout the play both Bohr and Heisenberg, in fact, question and try to find out how their scientific work during the war served politics. As Heisenberg says, "[Physics and politics] are sometimes painfully difficult to keep apart" (18), and Bohr and Heisenberg try to remember whether they achieved to separate physics from politics in time of war. Based on this, it may also be argued that the whole play is based on remembrance, and not only is the 1941 meeting remembered but also the important political and historical events of the period are presented. Each time the characters re-enact the meeting through their personal memories, they travel to the depths of history. Bohr refers to the political repression against the Jews in Germany and how this was reflected in science and affected scientific developments. He maintains that the achievements of the Jews in theoretical physics were despised, which resulted in the underestimation of the theoretical physics. According to Bohr, "[...] Because theoretical physics, the sort of physics done by Einstein, by Schrödinger and Pauli, by Born and Sommerfeld, by [Heisenberg] and me, was always regarded in Germany as inferior to experimental physics, and the theoretical chairs and lectureships were the only ones that Jews could get" (18). Moreover, the audience/readers learn that Otto Frisch and Rudolf Peierls, the two scientists who already did the calculation for atomic bomb, worked at the University of Birmingham instead of carrying out the research in Germany just because they were Jews (83).

\section{Conclusion}

Copenhagen brings a new perspective to a historical event which has remained as mystery for ages. David Cassidy describes what Heisenberg told Bohr in the 1941 meeting as "[...] the greatest remaining mystery of the war" $(2005,21)$. Thus, in the play the following question that Michael Eckert asks is discussed through various drafts of the real meeting between the two physicists: "Did Heisenberg want to persuade Bohr to collaborate on a German atomic bomb project? Or, on the contrary, did he have in mind to win Bohr over to a general boycott against developing atomic bombs?" $(2005,23)$. In the play, the historical characters not only reevaluate the making and using of atomic bomb but also try to see which sides they, consciously and unconsciously, took in the whole process by attempting to bring their conversation in 1941 to light through their personal memories which contradict each other. And all the recollections of the visit in the play are sum of the things the two physicists could and could not tell each other in their brief meeting in Copenhagen in 1941. Thus, "Frayn does not solve the puzzle for the audience. He merely explores the situation in several permutations" (Young 1999, 219), and "the play concerns motivations for human actions and the uncertainty of even individuals knowing why they do what they do" (Young 1999, 218). Though certain countries politically emerged victorious from World War II, mankind was defeated by new means of massive destruction. In the war fought between Bohr and Heisenberg in 1941 neither wins because while they try to justify their parts in the wartime research and work on atomic bomb through their personal memories, they end up questioning their own motivations. Frayn does not favour a side; instead, he wholly maintains the historical controversy over the 1941 meeting between Bohr and Heisenberg and leaves the historical question, "Why did Heisenberg visit Bohr in Copenhagen in 1941?" to the audience/readers to find a certain answer, if possible. What Frayn 
does to help the audience/readers on this historical, scientific and political journey is to present the physicists as scientists who are responsible to their people and as human beings with inner conflicts, desire to escape harsh reality but still with conscience. In a sense, the play presents Frayn's (1997) following assertion: "We are everything and nothing. We are responsible for everything, and responsible for nothing" (xiv).

\section{Note of the Author:}

This article is the expanded and revised version of the paper presented at $V^{\text {th }}$. International Western Cultural and Literary Studies Symposium: Memory (4-6 October 2017) organised by Cumhuriyet University, Sivas, Turkey.

\section{REFERENCES}

Aaserud F. (2002, February). "Introductory Comments". Niels Bohr Archive. Source: <http://www. nbarchive.dk/collections/bohr-heisenberg/introduction/>.

Baddeley A. D. (1999). Essentials of Human Memory. East Sussex 1999.

Barnett D. (2005). "Reading and Performing Uncertainty: Michael Frayn's Copenhagen and the PostDramatic Theatre". Theatre Research International 30 (2005) 139-149. Doi: 10.1017/S0307883305 001148.

Bohr A. (1985). "The War Years and the Prospects Raised by the Atomic Wepons". Ed. S. Rozental, Niels Bohr: His Life and Work as Seen by His Friends and Colleagues (1985) 191-215. Amsterdam.

Bohr N. (n.d.). "Document 1". Niels Bohr Archive. Source: <http://www.nbarchive.dk/collections/bohrheisenberg/documents/>.

Bohr N. (1961). "Document 5a". Niels Bohr Archive. Source: <http://archon.nbi.dk/tms/heisenberg/?doc= facs05a\&page $=1>$.

Bohr N. (n.d.). "Document 7". Niels Bohr Archive. Source: $<$ http://www.nbarchive.dk/collections/bohrheisenberg/documents/>.

Bohr N. (n.d.). "Document 9". Niels Bohr Archive. Source: $<$ http://www.nbarchive.dk/collections/bohrheisenberg/documents/>.

Bohr N. (n.d.). "Document 11a". Niels Bohr Archive. Source: <http://www.nbarchive.dk/collections/bohrheisenberg/documents/>.

Cassidy D. C. (1992). Uncertainty: The Life and Science of Werner Heisenberg. New York 1992.

Cassidy D. C. (2005). “Copenhagen and History”. Ed. M. Dörries, Michael Frayn's Copenhagen in Debate: Historical Essays and Documents on the 1941 Meeting between Niels Bohr and Werner Heisenberg (2005) 19-23. Berkeley.

Cropper W. H. (2001). Great Physicists: The Life and Times of Leading Physicists from Galileo to Hawking. Oxford 2001.

Dasenbrock R. W. (2004). “Copenhagen: The Drama of History”. Contemporary Literature 45/2 (2004) 218-238.

"Document 6". (n.d.). Niels Bohr Archive Source: <http://www.nbarchive.dk/collections/bohr heisenberg /documents/>.

Douglas A. \& Vogler T. A. (2003). "Introduction". Eds. A. Dougless \& T. A. Vogler, Witness \& Memory: The Discourse of Trauma (2003) 1-55. New York \& London.

Dower J. W. (1996). "The Bombed: Hiroshimas and Nagasakis in Japanese Memory”. Ed. M. J. Hogan, Hiroshima: In History and Memory (1996) 1-37. Cambridge.

Dörries M. (2005). "Introduction”. Ed. M. Dörries, Michael Frayn's Copenhagen in Debate: Historical Essays and Documents on the 1941 Meeting between Niels Bohr and Werner Heisenberg (2005) i-1. Berkeley.

Eckert M. (2005). "He Who Plays for Vulgar Ears Plays a Vulgar Tune". Ed. M. Dörries, Michael Frayn's Copenhagen in Debate: Historical Essays and Documents on the 1941 Meeting between Niels Bohr and Werner Heisenberg (2005) 23-31. Berkeley. 
Ermenc J. J. (1989). “Interview”. Atomic Bomb Scientists: Memoirs, 1939-1945 (1989) 9-77. Westport \& London.

Frayn M. (1997). "Introduction". Michael Frayn: Plays 1 (1997) ix-xix. London.

Frayn M. (1998). Copenhagen. London 1998.

Gottstein K. (2002). "New Insights?: Heisenberg's Visit to Niels Bohr in 1941 and the Bohr Letters". Source: $<$ https://arxiv.org/ftp/physics/papers/0610/0610270.pdf $\$$.

Heisenberg W. (1957, January 18). Two Letters from Werner Heisenberg to Robert Jungk, the Author of Brighter Than a Thousand Suns Source: <http://webcache.googleusercontent.com/search?q=cache :http://wernerheisenberg.unh.edu/Jungk.htm\&gws_rd=cr\&dcr=0\&ei=YvsfWpKROoTTwAKdza7oCQ>.

Heisenberg W. (1985). "Quantum Theory and Its Interpretation”. Ed. S. Rozental, Niels Bohr: His Life and Work as Seen by His Friends and Colleagues (1985) 94-109. Amsterdam.

Heisenberg W. \& Heisenberg E. (2016). My Dear Li: Correspondence, 1937-1946. Trans. I. Heisenberg. New Haven \& London 2016.

Hogan M. J. (1996). "Hiroshima in History and Memory: An Introduction". Ed. M. J. Hogan, Hiroshima: In History and Memory (1996) 1-37. Cambridge.

James I. (2004). Remarkable Physicists: From Galileo to Yukawa. Cambridge 2004.

Lesáková T. (2014). Memory and Uncertainty in Michael Frayn's Copenhagen. Unpublished Diploma Thesis. Charles University, Prague 2014.

Lustig Harry \& Shepherd-Barr K. (2002). "Science as Theatre: From Physics to Biology, Science is Offering Playwrights Innovative Ways of Exploring the Intersections of Science, History, Art, and Modern Life". American Scientist 90/6 (2002) 550-555.

Lüst R. (2004). "Heisenberg and the Scientist's Responsibility". Eds. G. W. Buschhorn \& J. Wess, Fundamental Physics - Heisenberg and Beyond (2004) 5-25. New York.

Magill F. N. (1999). The 20th Century Go-N: Dictionary of World Biography. New York 1999. "Niels Bohr - Biographical". (2014). Source: <https://www.nobelprize.org/nobel_prizes/physics/laureates/ 1922/bohr-bio.html>.

Pais A. (1991). Niels Bohr's Times: In Physics, Philosophy, and Polity. Oxford 1991.

Parkin A. (1999). Memory: A Guide for Professionals. West Sussex 1999.

Plotnitsky A. (2013). Niels Bohr and Complementarity: An Introduction. New York 2013.

Rosenfeld L. \& Rüdinger E. (1985). "The Decisive Years 1911-1918”. Ed. S. Rozental, Niels Bohr: His Life and Work as Seen by His Friends and Colleagues (1985) 38-74. Amsterdam.

Selden M. (1989). "Introduction". Eds. Kyoko \& Mark Selden, The Atomic Bomb: Voices from Hiroshima and Nagasaki (1989) xi-3. New York.

"Werner Heisenberg - Biographical". (2014). Source: <https://www.nobelprize.org/nobel_prizes/physics/ laureates/1932/heisenberg-bio.html>.

Wilczek G. (2010). Important Scientists and Philosophers of Our Times. Munich 2010.

Wu D. (2000). "Interview". Making Plays: Interviews with Contemporary British Dramatists and Their Directors. (2000) 209-232.

Young P. B. (1999). "Copenhagen by Michael Frayn [Review of the play Copenhagen]". Theatre Journal 51/2 (1999) 218-219. 